\title{
Effect of Modified Pre-Milking Sanitizing Approaches on Raw Milk Quality Obtained from the Dairy Farmers of Tawau Area, Sabah
}

\author{
Sim Kheng Yuen ${ }^{1 *}$, Mohammad Raisul Alam² \\ ${ }^{1}$ Faculty of Agro-Based Industry, University Malaysia Kelantan, 17600 Jeli, Kelantan, Malaysia \\ ${ }^{2}$ Faculty of Sustainable Agriculture, University Malaysia Sabah, 90000 Sandakan, Sabah, Malaysia
}

\section{A R T I C L E I N F O}

\section{Article history:}

Received 09 April 2015

Accepted 16 November 2015

Available online, ISSN: 2148-127X

Keywords:

Raw milk hygiene

Safety

Sanitizing practices

Chilling

Milk collecting syste

${ }^{*}$ Corresponding Author: E-mail: asim3975@gmail.com

\section{A B S T R A C T}

The aim of the study was to investigate the raw milk hygiene and quality among the small holder dairy farmers in Tawau area. A total of 216 samples were collected from the respective dairy farmers and milk collecting centre located at Mile 15, Tawau. Preliminary results indicated that the quality of the raw milks obtained at farm level contained were inferior with high bacteria load (> than $10^{7} \mathrm{CFU} / \mathrm{ml}$ ). The total coliform (2.9-3.8 CFU/mL) and Staphylococcus count (2.3-3.6 CFU/mL) were relatively high in certain samples. However, none of the food borne pathogens was found. Trace back study revealed that the causes of contamination were attributed by poor hygienic handling among the dairy farmers and insufficient for immediate chilling of raw milk. A significant reduction in bacteria load was observed if the raw milk chilled immediately at farm. The implementation of modified pre-milking sanitizing practices improved the microbiology quality of the raw milks obtained from respective dairy farms. Future study will focus more on the effect of prolong storage towards the microbiological quality of raw milk.

\section{Introduction}

Milk is a food of good nutritional value which ensures benefits from its consumption. However, it serves as a good medium for microbial grow namely Lactobacillus, Leuconostoc, Lactococcus, Streptococcus, Enterococcus, yeast, moulds and Enterobacteria. Studies showed that foodborne pathogens include Listeria monocytogenes, Salmonella, Campylobacter, Staphylococcus aureus, Bacillus cereus, Clostridium botulinum and Shigella were associated with contaminated raw milk Millogo et al. (2009). Meanwhile, the detection on coliform bacteria or pathogens in milk can considered as indicator on the hygienic level along the milking process. The high bacterial count and the present of pathogenic bacteria not only degrade the milk quality and shelf-life of milk, but it also poses serious threat to consumers. Hence, many dairy programs have been carried out to improve the production as well as quality of raw milk. This includes: keeping and storing the milk in clean containers at refrigerated temperature $\left(4^{\circ} \mathrm{C}\right)$ immediately after milking process, control and modification on milking process or environment to eliminate cross contamination on raw milk harvested from milk utter.

The milk production in Sabah is more towards selfsufficiency with an annual production that exceeding $7 \mathrm{~m}$ litters. Nevertheless, most of the small-scale farmers neglect the importance of good hygiene practices along the milking line which will affect the raw milk quality and also create economic loses to them. Therefore, this study is undertaken to investigate the raw milk hygiene and quality among the dairy farmers in Tawau area and on what dairy programs can be implemented to improve the milk quality and production in that area.

\section{Materials and Methods}

\section{Sample Collection}

An approximately $100-300 \mathrm{ml}$ of raw milk samples were collected from 8 different farmers in Tawau area. In addition, the milk were taken from respective collector churns that send by each farmer at Milk Collecting Center (MCC), station Mile 8, Tawau before transported back to Food Bioprocessing Laboratory, Faculty of Sustainable Agriculture, Universiti Malaysia Sabah (UMS). The milk samples were stored properly using cooler box contain dry ice that maintained the temperature $4-5^{\circ} \mathrm{C}$.

\section{Microbiological Analysis of Milk Samples}

The milk samples were tested for total plate (TP), total coliform (TC) and total Staphylococcus (TS) count using respective agar mediums, namely the plate count agar (PCA), violet RB agar and Baird Pard agar (BPA). The milk samples were also detected for the presence of pathogenic organisms, namely Listeria monocytogenes, E. coli H7:0157 and Salmonella typhimurium as (ISO, 1990). 


\section{Modified Premilking Teat-Cleaning and Sanitization Procedures}

Slight modification on the premilking teat-cleaning and sanitizing procedures were introduced to the farmers. During the milking stage, each farmers will be provided with an individual wet water wash wipe (50\% ethanol $\mathrm{v} / \mathrm{v})$, an iodine-based dip for $15 \mathrm{~s}$ and individual dry towel. The use of hot water to clean the milking utensils namely the milking teats, chunks, milk collectors and the milking area was implemented after every milking session.

\section{Statistical Analysis}

The data were collected and analyzed using analysis of variance (ANOVA) which applied a Duncan multiple test The statistical analysis was performed using SPSS version 17.0 (SPSS Inc. Chicago).

\section{Results and Discussion}

Comparison of the Microbial Quality between Dairy Farmers and Milk Collecting Center (MCC)

A total of 216 raw milk samples were collected from eight farmers and MCC. The bacteriological quality of most raw milk samples was low, with a total plate count exceeding $10^{6} \mathrm{CFU} / \mathrm{ml}$ (Table 1). The poor microbiological quality of the raw milk could be associated to improper hygienic practices throughout the milking process (Gran et al., 2002). Farm F5 recorded the highest TPC (7.24 $\log \mathrm{CFU} / \mathrm{ml})$ which might due to improper milking procedures among farmers. In addition, ineffective sanitizing routine on farm shelter that leaving herds' manure in contact with cows' udder also contributed to the high bacterial level in raw milk. On contrary, both the coliform $(2.31-3.80 \log \mathrm{CFU} / \mathrm{ml})$ and
Staphylococcus counts $(2.11-3.47 \log \mathrm{CFU} / \mathrm{ml})$ were high in all tested samples. The high in Staphylococcus counts revealed the poor personal hygiene among personnel throughout milking line. Meanwhile, the bacterial load of milk samples obtained from MCC was slightly higher than the farm level (Table 1). For instance, the TPC count obtained from farmer F4 was $5.78 \pm 0.17$ and their count increased to $6.13 \pm 0.18 \log \mathrm{CFU} / \mathrm{ml}$ at the MCC level. The significant increase $(\mathrm{p}<0.05)$ of the TPC was attributed to the delay in chilling down the fresh milk to $4-5^{\circ} \mathrm{C}$ by farmers after milking process. The current result was in accordance to the statements given by International Dairy Federation (1990) on the violation of any temperature will result in the increase of microorganisms in the milk.

Meanwhile, a comparison on the milk quality obtained from bulk tank and chilled milk from farm level was conducted (Table 2). The result showed that the fresh milk that immediately chilled to $4-5{ }^{\circ} \mathrm{C}$ after milking process had significant lower $(\mathrm{P}<0.05)$ bacterial load $(3.36 \pm 0.10 \log \mathrm{CFU} / \mathrm{ml})$ as compared to milk obtained from the bulk tank without refrigeration $(6.72 \pm 0.15 \mathrm{log}$ $\mathrm{CFU} / \mathrm{ml}$ ). Meanwhile, the spoilage bacteria (coliform and Staphylococcus) were notably reduced below detectable level. This indicated that immediate cooling on fresh milk after milking can reduce the proliferation of microorganism. It also ensures safer fresh milk with better quality to be sent to MCC for further process. According to Ritchter et al. (1992), the fresh milk withdrawn from a healthy cow normally has low microbial count $(<1000$ $\mathrm{CFU}$ ). However, the load may increase to 100 fold or more if external contamination or temperature abuse taken place along the milking chains.

Table 1 The microbiology quality of raw milks obtained from individual farms and MCC

\begin{tabular}{c|cccccc}
\hline \multirow{2}{*}{$\begin{array}{l}\text { Load (log CFU/ml) } \\
\text { Sample }\end{array}$} & \multicolumn{2}{|c}{ Total plate count } & \multicolumn{2}{c}{ Total coliform count } & \multicolumn{2}{c}{ Total Staphylococcus count } \\
\cline { 2 - 7 } Farm & MCC & Farm & MCC & Farm & MCC \\
\hline F1 & $5.13 \pm 0.12^{\mathrm{f}}$ & $5.22 \pm 0.03^{\mathrm{f}}$ & $2.31 \pm 0.12^{\mathrm{d}}$ & $2.65 \pm 0.22^{\mathrm{e}}$ & $2.11 \pm 0.04^{\mathrm{f}}$ & $2.32 \pm 0.16^{\mathrm{e}}$ \\
F2 & $6.52 \pm 0.13^{\mathrm{c}}$ & $6.38 \pm 0.12^{\mathrm{d}}$ & $3.19 \pm 0.03^{\mathrm{b}}$ & $3.36 \pm 0.27^{\mathrm{b}}$ & $2.54 \pm 0.05^{\mathrm{c}}$ & $2.75 \pm 0.20^{\mathrm{bc}}$ \\
F3 & $6.89 \pm 0.18^{\mathrm{b}}$ & $6.96 \pm 0.27^{\mathrm{b}}$ & $3.29 \pm 0.04^{\mathrm{b}}$ & $3.51 \pm 0.25^{\mathrm{a}}$ & $2.72 \pm 0.13^{\mathrm{bc}}$ & $3.13 \pm 0.04^{\mathrm{ab}}$ \\
F4 & $5.78 \pm 0.11^{\text {ef }}$ & $6.13 \pm 0.14^{\mathrm{de}}$ & $2.84 \pm 0.22^{\mathrm{c}}$ & $2.97 \pm 0.17^{\mathrm{d}}$ & $2.65 \pm 0.08^{\mathrm{c}}$ & $2.98 \pm 0.13^{\mathrm{b}}$ \\
F5 & $7.24 \pm 0.17^{\mathrm{a}}$ & $7.58 \pm 0.17^{\mathrm{a}}$ & $3.80 \pm 0.18^{\mathrm{a}}$ & $3.20 \pm 0.23^{\mathrm{c}}$ & $3.23 \pm 0.16^{\mathrm{a}}$ & $3.47 \pm 0.06^{\mathrm{a}}$ \\
F6 & $6.97 \pm 0.15^{\mathrm{b}}$ & $6.70 \pm 0.07^{\mathrm{c}}$ & $3.66 \pm 0.09^{\mathrm{a}}$ & $3.41 \pm 0.18^{\mathrm{ab}}$ & $3.07 \pm 0.17^{\mathrm{b}}$ & $3.15 \pm 0.15^{\mathrm{a}}$ \\
F7 & $6.16 \pm 0.09^{\mathrm{d}}$ & $6.59 \pm 0.16^{\mathrm{c}}$ & $3.21 \pm 0.16^{\mathrm{b}}$ & $3.15 \pm 0.05^{\mathrm{c}}$ & $2.32 \pm 0.14^{\mathrm{de}}$ & $2.46 \pm 0.15^{\mathrm{cd}}$ \\
F8 & $5.95 \pm 0.22^{\mathrm{e}}$ & $6.07 \pm 0.22^{\mathrm{e}}$ & $2.70 \pm 0.17^{\mathrm{c}}$ & $3.42 \pm 0.24^{\mathrm{a}}$ & $2.26 \pm 0.07^{\mathrm{e}}$ & $2.53 \pm 0.18^{\mathrm{c}}$ \\
\hline
\end{tabular}

MCC - Milk Collection Center; Means with different letters within a row are significantly different $(\mathrm{P}<0.05)$; Same alphabet horizontally shows no significance difference at 0.05

Table 2 Comparison of microbial loads among bulk and chilled samples

\begin{tabular}{l|ccc}
\hline Samples & $\begin{array}{c}\text { Total Plate Count } \\
(\log \text { CFU/ml })\end{array}$ & $\begin{array}{c}\text { Total Coliform Count } \\
(\log \text { CFU/ml })\end{array}$ & $\begin{array}{c}\text { Total Staphylococcus count } \\
(\log \text { CFU/ml })\end{array}$ \\
\hline$*$ Bulk tank & $6.72 \pm 0.15^{\mathrm{a}}$ & $3.19 \pm 0.18^{\mathrm{a}}$ & $3.22 \pm 0.20^{\mathrm{a}}$ \\
$* *$ Chilled tank & $3.36 \pm 0.10^{\mathrm{b}}$ & $2.28 \pm 0.15^{\mathrm{b}}$ & $2.12 \pm 0.17^{\mathrm{b}}$ \\
\hline
\end{tabular}

Figures in bracket represent number of samples tested; *Milk obtained from bulk tank (temporary) without refrigeration; **Milk that immediately chilled to $4-5{ }^{\circ} \mathrm{C}$ after milking process; Means with different letters within a row are significantly different $(\mathrm{P}<0.05)$ 


\section{Detection on Pathogenic Organisms for All tested Samples}

Fresh milk normally contains low level of bacterial load as well as presence of certain pathogenic bacteria. Nevertheless, the presence of indicator organisms such as E. coli and coliform bacteria indicates contamination might occurs during the milk supply chain. Generally, the occurrence of pathogenic organisms in the raw milk samples was low among all tested samples (Table 3). A total of 16 samples (out of 150) was tested positive for the presence of E.coli among the milk samples obtained from respective farmers. Nevertheless, samples obtained from farmer F3, F5 and F8 recorded highest prevalence of $E$. coli $(25.0 \%)$. However, this E.coli was not originated from the food borne species (E. coli O157: H7). Their presence in milk usually associated with faecal contamination of water sources or poor hygiene practices during milking process. The result was in accordance to the finding of Chye et al. (2004).

Another pathogen that related to the food hygiene and quality was Staphylococcus spp (Staphylococcus aureus). They tend to degrade the milk quality once they multiplied tremendously and the whole batch of milk will spoil prior sending for processing. It was observed that the Staphylococcus aureus was the second prevalence pathogenic bacteria that detected in this study. They were found in the range of $11.1-33.3 \%$ among the tested samples and this phenomenon might due to different milking technique among the farmers. In fact, the Staphylococcus aureus was originated from infected cattle with mastitis problem or improper handling practices. According to Rysanek et al. (2007) mastitis was usually caused by contagious pathogens namely Staphylococcus aureus and Streptococcus agalactiae than mastitis caused by environmental pathogens such as Streptococcus uberisand Escherichia coli. Hence, an effective postmilking practices including proper disinfection on cattle's teat or workers' hand are imperative to solve the prevalence of these pathogens in raw milk.

Both the Salmonella and Listeria spp were seldom detected in whatever period of this study. Only 5 and 3 (of 150 samples) raw milks were found positive to the presence of Salmonella and Listeria spp, respectively Till date, the occurrence of Salmonellosis in local raw milk product was still low, however they still pose a health threatening diseases especially typhoid fever to the consumers who consumed any milk product that might contains Salmonella spp. The present of Salmonella spp in raw milk was mostly due to the post-processing contamination starting from the milking system to the supply chain. Most of the processors use heat treatment such as pasteurization to eliminate the heat sensitive Salmonella spp that may found in raw milk.

\section{Effect of Pre-milking Treatments on the Raw Milk Quality}

The implementation of pre-milking cleaning practice resulted in a slight improvement on the raw milk microbiological quality (Table 4). Both the microbial load on the teat as well as the raw milk was significantly reduced to an accepted level prior further processing. For instant, the microbial load of the teat reduced $19 \%$ (F4) while the raw milk also showed steady reduction of $12.7 \%$ for similar tested sample. This clearly indicated the use of hot water to sanitize the milking utensils is very effective to minimize the proliferation of microorganisms. Besides, the use of individual dry towel and hot water wash wipe (50\% ethanol) throughout milking process also contributed to the decrease of microbial load. Studies done by Bonfoh et al. (2006) revealed that the importance of proper cleaning on the utensils and personnel hygiene in maintaining the quality of raw milk. The current study revealed that the combination of hot water wash wipe with low ethanol concentration is a promising and cost effective approach to disinfect the cow's teat. Furthermore, this approach did not pose any side effects as compared to those using chemical disinfectants. Hence, in the future more premilking cleaning practices should be implemented among the farmers in order to upgrade the quality of raw milk within Sabah regions.

\section{Conclusion}

In accordance with this research result, raw milk quality of local farmers within Tawau region was very low. High bacterial loads as well as presence of several pathogenic bacteria in above samples might affect the raw milk quality or pose threats to consumer. This study suggested that dairy farmers should chill the raw milk immediately after milking and reduce the holding time prior sent to MCC for a better raw milk quality. Furthermore, the use of modified pre-milking treatment was able to reduce the microbial count to an acceptable level in whatever duration of the study and it should be practiced by small holder dairy farmers in order to improve their raw milk quality.

Table 3 Prevalence of pathogenic bacteria in raw milk obtained from different farmers

\begin{tabular}{c|ccccc}
\hline \multirow{2}{*}{ Farmer } & \multirow{2}{*}{ Number of samples } & \multicolumn{4}{c}{ Num. of positive sample (\%) } \\
\cline { 2 - 5 } & & E-coli & Staphylococcus aureus & Salmonella spp. & Listeria spp. \\
\hline F1 & 18 & $1(5.6)$ & $2(11.1)$ & - & $1(8.3)$ \\
F2 & 12 & $1(8.3)$ & $2(16.7)$ & $1(8.3)$ & - \\
F3 & 12 & $3(25.0)$ & $2(16.7)$ & - & $1(8.3)$ \\
F4 & 12 & $1(8.3)$ & $2(16.7)$ & $1(8.3)$ & $1(8.3)$ \\
F5 & 12 & $3(25.0)$ & $4(33.3)$ & - & - \\
F6 & 12 & $2(16.7)$ & $3(25.0)$ & $1(8.3)$ & - \\
F7 & 12 & $2(16.7)$ & $3(25.0)$ & $1(8.3)$ & - \\
F8 & 12 & $3(25.0)$ & $2(16.7)$ & $5(3.3)$ & $3(2.0)$ \\
\hline Total & 150 & $16(10.7)$ & $20(13.3)$ & &
\end{tabular}


Table 4 The teat total plate count (TPC) levels before and after pre-milking cleaning procedures

\begin{tabular}{c|cccccc}
\hline \multirow{2}{*}{ Sample } & \multicolumn{3}{|c}{ Teat $(\log$ CFU/ml) } & \multicolumn{3}{c}{ Raw milk $(\log$ CFU/ml) } \\
\cline { 2 - 7 } & Before & After & Difference & Before & After & Difference \\
\hline F1 & 3.22 & 2.98 & $-0.24(7.5 \%)$ & 5.45 & 5.01 & $-0.44(8.1 \%)$ \\
F2 & 4.07 & 3.54 & $-0.53(13 \%)$ & 6.14 & 5.36 & $-0.78(13 \%)$ \\
F3 & 3.97 & 3.21 & $-0.76(19 \%)$ & 6.53 & 5.97 & $-0.56(8.6 \%)$ \\
F4 & 3.76 & 3.02 & $-0.74(20 \%)$ & 5.98 & 5.22 & $-0.76(13 \%)$ \\
F5 & 5.48 & 4.86 & $-0.62(11 \%)$ & 7.19 & 6.62 & $-0.57(7.9 \%)$ \\
F6 & 4.02 & 3.75 & $-0.27(6.7 \%)$ & 6.31 & 6.07 & $-0.30(3.8 \%)$ \\
F7 & 3.45 & 3.07 & $-0.38(11 \%)$ & 5.87 & 5.35 & $-0.52(9.8 \%)$ \\
F8 & 4.11 & 3.72 & $-0.39(9.5 \%)$ & 5.34 & 5.06 & $-0.28(5.2 \%)$ \\
\hline
\end{tabular}

Figures in bracket indicate the difference in percentage (\%)

\section{Acknowledgements}

The authors wish to thank the Universiti Malaysia Sabah for funding this research. A special thanks to the Department of Veterinary Services Sabah and Sabah Dairy Association for providing useful information. The assistance of officers from Milk Collection Center (MCC), Station Mile 8, Tawau is also greatly appreciated

\section{References}

Bonfoh B, Roth C, Traore AN, Fane A, Simbe CF, Alfaroukh IO. 2006. Effect of washing and disinfecting containers on the microbiological quality of fresh milk sold in Barnako (Mali). Food Control., 17(2): 153-161.

Chye FY, Abdullah A, Ayob MK. 2004. Bacteriological quality and safety of raw milk in Malaysia. Food Microbiol., 21: 535-541.
Gran HM, Mutukumira AN, Wetlesen A,Narvhus JA.2002. Smallholder dairy processing in Zimbabwe: hygienic practices during milking and the microbiological quality of the milk at the farm and on delivery. Food Control., 13: 41-4.

International Dairy Federation. 1990. Handbook on milk collection in warm developing countries. Brussels.

International Standard Organization. 1990. Microbiology - General guideline on the method for the detection of Salmonella. International Standard Organization, Geneva, ISO 6579.

Millogo V, Ouedraogo GA, Agenas S, Svennersten-Sjaunja K. 2009. Day-to-day variation in yield, composition and somatic cell count of saleable milk in hand-milked zebu dairy cattle. Afr. J. Agric. Res., 4(3): 151-155.

Richter RL, Ledford RA,Murphy SC. 1992 Milk and milk products. In: Vanderzant, C., Splittstoesser, D.F. (Eds.), Compendium of Methods for the Microbiological Examination of Foods, $3^{\text {rd }}$ Edition. American Public Health Association, Washington, DC.

Rysanek V, Babak M, Zouharova K. 2007. Bulk tank milk somatic cell count and source of raw milk contaminations with mastitis pathogens. Vet. J., 52: 223-230. 